\title{
Anatomical eponyms in Cardiology from to the 60 s to the XXI century
}

\author{
Epônimos anatômicos em Cardiologia dos anos 60 ao século XXI
}

\author{
Alexandre Lins WERNECK ${ }^{1}$, Fernando BATIGÁLIA²
}

RBCCV 44205-1251

\section{Resumo}

Introdução: Epônimo, do Grego [epi, "sobre"] + [ónoma, nome de pessoa ou objeto], é uma pessoa, real ou fictícia, que dá ou empresta seu nome a alguma coisa. Epônimos são usados diariamente na Medicina, nos anos de clínica médica, e são parte da tradição, cultura e da história da Medicina. Os epônimos nos conectam com as mentes notáveis do passado, trazem vida à Medicina. Há muitas pessoas que ficariam felizes em defender que os epônimos devem se abolidos, mas, no entanto, as propostas nas entrelinhas de tal raciocínio não chegam sequer a convencer parte dos profissionais de Saúde Pública. Usam amiúde uma alegação bastante fraca: falta-lhes precisão, levam à confusão, impedem o debate científico e são, meramente, um "ponto de apoio". Muitas vezes, a pessoa homenageada nem foi a primeira a descrever a condição, são difíceis de aprender, imprecisos, redundantes, etnocêntricos e assim por diante. Apesar de toda a inconveniência, todos aqueles favoráveis ao uso dos epônimos fazem apenas uma singela afirmação: os epônimos em Medicina continuarão a ser usados porque há sentido histórico no seu uso. Estão em uso na vida moderna, ou seja, os epônimos estão aqui para ficar.

Métodos: O presente estudo tem como objetivo contextualizar a presença dos epônimos anatômicos de uso comum, usados nos mais renomados e conhecidos Atlas e Livros-Textos de Anatomia Humana, fazendo uma jornada do mais antigo ao mais recente, compreendendo o período dos anos 60 até o ano de 2011, considerando o sistema circulatório, especialmente o coração. As três Terminologias Anatômicas Internacionais foram essenciais como embasamento científico inconteste do presente estudo. Os critérios de exclusão foram síndromes, doenças, sinais, anomalias, procedimentos cirúrgicos, índices, escores, testes, classificações e métodos que são usados como epônimos em Cardiologia, uma vez que não são considerados termos anatômicos. $O$ propósito do presente estudo foi mostrar que diferentes epônimos representam a mesma estrutura anatômica.

Resultados: Uma lista com os 25 epônimos mais comuns listados pela Terminologia Anatômica Internacional é apresentada na Tabela 1.

Conclusão: Os epônimos devem ser banidos? Claro que não, porque permanecem como uma reflexão útil da história médica. Provamos, por meio de uma jornada dos anos 60 até 2011, que os melhores Atlas e Livros-Textos de Anatomia Humana disponíveis não usam tantos epônimos em Cardiologia. São apenas 25 (com a exclusão de artérias, veias e nervos do sistema circulatório), e todos os autores não usam mais do que nove ou 12 epônimos. Gostaríamos apenas de alertar os profissionais e estudantes da área de Saúde e ciências correlatas que o uso de epônimos é "extremamente contrarrecomendado", quando utilizado às custas de uma estrutura anatômica.

Descritores: Cardiologia. Anatomia. Epônimos. Terminologia.

\footnotetext{
Abstract

Background: Eponym from the Greek [epi, "upon"] + [onuma, name], is a person, whether real or fictitious, after whom an item is named or thought to be named. Eponymous terms are used every day in Medicine, in our clinical years, and they have been part of the tradition of Medicine, culture, and history. Despite all the inconvenience, all those who are no against eponym has only one statement: "medical
}

1. Translator. Master's Degree on Health Science; Postgraduate Doctoral Student; Health Sciences Stricto Sensu Post-Graduate Programme; São José do Rio Preto Medical School (FAMERP).

2. M.D. Human Anatomy Tutor; Health Sciences Stricto Sensu PostGraduate Programme; São José do Rio Preto Medical School (FAMERP).
Endereço para correspondência:

Alexandre Lins Werneck

Rua Rio Mamoré, 287 - Jardim Aclimação - São José do Rio Preto, SP, Brasil - CEP 15091-410.

E-mail: alexandrewerneck@uol.com.br 
eponyms will continue to be used because there is a sense of history to their use. They are use in contemporary life, eponyms are here to stay".

Methods: The following study aims at to show the presence of current anatomical eponyms on the best wellknown Textbooks and Atlas of Human Anatomy, ranging from the oldest to the newest one, comprising a period from 1960 until 2011, regarding the cardiovascular system, particularly the heart. The three International Anatomical Terminologies have been critical as the basis of our study. Exclusion criteria were syndromes, diseases, signs, anomalies, surgical procedures, indexes, tests, grading, and the methods, which are used as eponyms in Cardiology, once they are not considered Anatomical Terms. It has been our intent to show that different eponyms characterize the same anatomical structure.
Results: A list with the $\mathbf{2 5}$ most common eponyms listed by the three International Anatomical Terminologies is listed in Table1.

Conclusion: Should eponyms be abandoned? Of course not, once they remain a useful reflection of medical history. We could prove to our journey from 1960 to 2011, that the best well-known Atlas and Textbooks available do not use so many anatomical eponyms in Cardiology. They are only 25 (without including arteries, veins, and nerves of the cardiovascular system) and all the authors use no more than 9 or 12 of them. We just want to alert the Health and Allied Health Sciences Professional and students that we 'strongly recommend' not to use an eponym when it is made at the expense of an anatomical structure.

Descriptors: Cardiology. Anatomy. Eponyms. Terminology.

\section{INTRODUCTION}

Vesalius concluded the preface of his Fabrica (1543) with the following statement about anatomy: "Anatomy should rightly be regarded as the firm foundation of the whole art of Medicine and its essential preliminary" [1,2]. Abraham Colles [2] stated in 1811 that "it is a mistake to consider anatomy in no other light than as a science itself... instead of considering it as a science altogether subservient to the practice of Medicine and surgery". Hippocrates [3] stated: "The nature of the body is the beginning of medical science". With those statements as guiding principles, it is the aim of the article to provide a list of anatomical eponyms used in Cardiology, many of which are in common usage.

Anatomy is the science of the structure of the body - is one of the oldest basic medical sciences, being first studied formally in Egypt (approximately 500 BC) [3]. The term is derived directly from the Greek anatemno, a term built from ana, meaning "up", and temno, meaning "to cut" and so "a dissection" [4]. The term anatome was first used by Aristoteles (384-322 BC), which is a Greek word meaning, "cutting up or taking apart". The Latin word dissecare has the same meaning [3].

After centuries of accumulating terms to name parts of human body, a group of renowned anatomists prepared a list of names to serve as worldwide official standard vocabulary for all health sciences. In 1895 this list, with a standard Latin anatomical nomenclature, became known as the Basle Nomina Anatomica (BNA). It was introduced an adopted in many countries and to a large extent dispelled the confusion exiting up till that time [5]. This was the first attempt to offer a basis for universal agreement on the use of terms related to the human body, both for anatomy and the other health sciences. The same terminology would eliminate national differences that were causing extreme confusion because the same

structure was known by several names, and the anatomical terms sometimes included the name of one or more scientists to honor those who has first described, draw attention to, demonstrate the meaning of, or correctly interpreted a particular structure [6].

The students will often hear their teachers refer to structures by the name of the man who discovered or first described them, and later in hospital they may hear them called only by these names. Yet Anatomy began as a descriptive science in the days when Latin was the universal scientific language, the early anatomists described the structures they saw in that language, comparing them to common and familiar objects, or borrowing terms from the Greek and Arabic masters before them [7]. Because this discrepancy may be a source of confusion, Eponyms terms incorporating names of people are not used in the new terminology because they give no clue about the type or location of the structures involved [3].

The word "eponym" is derived from the Greek "epi" which roughly means "upon" or "in addition", and "onyma" which means "name". Some of the earliest uses of eponyms were by the ancient Greeks and ancient Romans, who named their years after their magistrates consuls, respectively [8]. The older traditional Human Anatomical textbooks included numerous anatomical eponyms. This was a desire to perpetuate the memory of original investigators by associating their names with the anatomical structures that they had discovered. The current trends in most medical school curricula have reduced the subject matter in Human anatomy to its barest essentials with the elimination of all eponyms [9]. Sometimes, eponyms are used to honor not the discoverer, but to honor someone who is prominent in a particular filed [8].

Jacob Sylvius (1478-1555), the teacher of Vesalius, is generally regarded as the founder of anatomical 
nomenclature. There are many terms used to describe the 5,000 parts of the human body, but it is estimated that more than 50,000 terms were in use in Europe and North America to describe human gross anatomy. Some terms were based on Latin, some Greek, some German, some English, and thousands were eponyms. The result was the inability of physicians trained at different schools to communicate effectively with one another [10]. Sometimes, perhaps often, things are named falsely or wrongly after persons because of their high social status and high visibility in the field, long after a particular discovery had been made [11]. Anybody interested in fuller etymological details should consult one of the authorities mention in the references.

\section{METHODS}

The following study aims at to show the presence of current anatomical eponyms on the best well-known Textbooks and Atlas of Human Anatomy, ranging from the oldest to the newest one, comprising a period from 1960 until 2011, regarding the cardiovascular system, particularly the heart. The three International Anatomical Terminologies have been critical as the basis of our study. It has been used the following basic International Anatomical Terminologies: Terminologia Anatomica - International Anatomical Terminology - FCAT - Federative Committee on Anatomical Terminology, New York: Thieme Stuttgart, 1998 [12]; Terminologia Anatômica - Terminologia Anatômica Internacional - Sociedade Brasileira de Anatomia, filiada à FCAT (CFTA) Federative Committee on Terminological Terminology - Comissão Federativa da Terminologia Anatômica. São Paulo: Manole, 2001 [13]; and Terminología Anatómica - Terminología Anatómica Internacional - Sociedad Anatómica Española (SAE). Comité Federal sobre la Termiología Anatómica. Madrid: Médica Panamericana, 2001 [14], and their Official Anatomical Terms in Latin/Greek. Exclusion criteria were syndromes, diseases, signs, anomalies, surgical procedures, indexes, tests, grading, and the methods which are used as eponyms in Cardiology, once they are not considered Anatomical Terms. It has been our intent to show that different anatomical eponyms characterize the same anatomical structure.

\section{RESULTS}

After reviewing the literature and cataloging of eponyms, those relating to Cardiac Anatomy $(\mathrm{n}=25)$ are listed in Table 1.

\section{DISCUSSION}

Eponym terms are in daily use in Medicine. This system of nomenclature which simply commemorates a person is inconvenient, poses difficulties to students and leads to frequent mistakes in scientific writings [15]. According to Christian Nordqvist [16], writers such as Alexander Woywodt, Consultant Renal Physician, Renal Unit, Lancashire Teaching Hospitals NHS Trust, Preston, Lancashire PR2 9HT and Eric Matteson, Professor of Rheumatology, Mayo Clinic College of Medicine, Rochester, Minnesota, USA, argue that eponyms are not appropriate anymore because they believe we should drop them and stick to more explanatory terms. They cite eponyms which are linked to Nazi Medicine as some of the unsuitable one. "Eponyms lead to confusion and undermine scientific discussion", they say. Taking into consideration that in order to learn is necessary to understand history, those who argument that to use the name of someone who was vile is to celebrate them inappropriately, do not realize that history is what happened, not what we or the revisionists wish had happened [17].

Nevertheless, the use of eponyms is highly contentious. Some argue that healthcare professionals may be baffled by terms that do not accurately outline the condition, that eponyms may not necessarily reflect the truth of discoveries, and suggest eponyms be abandoned in favor of more descriptive terms. Eponyms certainly can have some rather annoying features; for example, many diseases have more than one eponym. Some authors even have multiple conditions ascribed to them so it may be taxing to distinguish which condition is being discussed [18]. Swee points out that another problem is that some eponyms do not refer to the same person. For example, the pick cell (foam cell), Pick's disease (a neuro-degenerative disorder) and Pick's pericarditis were name after, respectively - Ludwig Pick (a German pathologist), Arnold Pick (a Czech psychiatrist), and Friedel Pick (a Czech-Austrian physisician) [8]. Eponyms can differ between cultures (e.g., Behcet syndrome is often termed Adamantiades syndrome in Greece; Sjogren sundrome is termed Gougerot syndrome in France) [17]. A medical writer may be associated eponymously with more than one disease: Paget's disease of bone (osteitis deformans), Paget's disease of breast (intraductal carcinoma), von Recklinghausen's disease of bone (osteitis fibrosa cystica), von Recklinghausen's disease of skin (neurofibromatosis) [19].

Confusion is exacerbated by different use of eponyms, depending on which country they are utilized. Amidst this confusion, scientists are calling for a more descriptive classification of medical terms, particularly from specialties, which use eponyms extensively [16]. The same or condition can have more than one eponym designation if there is a difference of opinion as to who first described it. Thus Grave's diseasae, Basedow's disease, and Flaiani's disease are all synonymous terms for the same disease [19], as well as the Adams-Stokes syndrome, Adams-Stokes disease, 
Table 1. Current anatomical eponyms used in Cardiology from [12-14]

\begin{tabular}{|c|c|c|c|c|c|c|}
\hline ENGLISH & PORTUGUESE & SPANISH & LATIM/GREEK & ENGLISH & PORTUGUESE & SPANISH \\
\hline Arantius, bodies of & Corpos de Arâncio & Cuerpos de Arancio & $\begin{array}{l}\text { Noduli valvularum } \\
\text { semilunaurm }\end{array}$ & $\begin{array}{l}\text { Nodules of semilunar } \\
\text { cuspis }\end{array}$ & $\begin{array}{l}\text { Nódulos das } \\
\text { válvulas semilunares }\end{array}$ & $\begin{array}{l}\text { Nódulos de las } \\
\text { valvas semilunares }\end{array}$ \\
\hline Arantius, ligament of & Lig. de Arâncio & Lig. de Arancio & Lig. Venosum & Ligametum venosum & Lig. Venoso & Lig. venoso \\
\hline Aschoff-Tawara node & $\begin{array}{l}\text { Nó de Aschoff- } \\
\text { Tawara }\end{array}$ & $\begin{array}{l}\text { Nodo de Aschoff- } \\
\text { Tawara }\end{array}$ & $\begin{array}{l}\text { Nodus } \\
\text { atrioventricularis }\end{array}$ & Atrioventricular node & Nó atrioventricular & $\begin{array}{l}\text { Nodo } \\
\text { atrioventricular }\end{array}$ \\
\hline Botallos duct, ligament & $\begin{array}{l}\text { Ducto, Ligamento } \\
\text { de botal }\end{array}$ & $\begin{array}{l}\text { Conducto, } \\
\text { Ligamento de Botal }\end{array}$ & $\begin{array}{l}\text { Lig. arteriosum (Ductus } \\
\text { arteriosus) }\end{array}$ & $\begin{array}{l}\text { Ligamentum } \\
\text { arteriosum (Ductus } \\
\text { arteriosus) }\end{array}$ & $\begin{array}{l}\text { Lig. arterial (Ducto } \\
\text { arterial) }\end{array}$ & $\begin{array}{l}\text { Lig. arterioso } \\
\text { (Conducto arterioso) }\end{array}$ \\
\hline Botallos foramen & Forame de Botal & Foramen de Botal & (Foramen ovale cordis) & (Foramen ovale) & $\begin{array}{l}\text { (Forame oval do } \\
\text { coração) }\end{array}$ & (Foramen oval) \\
\hline $\begin{array}{l}\text { Drummond, Marginal } \\
\text { artery of }\end{array}$ & $\begin{array}{l}\text { Artéria marginal de } \\
\text { Drummond }\end{array}$ & $\begin{array}{l}\text { Arteria marginal de } \\
\text { Drummond }\end{array}$ & $\begin{array}{l}\text { A. marginalis coli; A. } \\
\text { juxtacolica; Arcus } \\
\text { marginalis coli }\end{array}$ & $\begin{array}{l}\text { Marginal artery; } \\
\text { juxtacolic artery; } \\
\text { Marginal arcade }\end{array}$ & Arco justacólico & $\begin{array}{l}\text { A. marginal del } \\
\text { colon; A, } \\
\text { yuxtacólica; Arco } \\
\text { marginal del colon }\end{array}$ \\
\hline Eustachian valve & Valva de Eustáquio & $\begin{array}{l}\text { Válvula de } \\
\text { Eustáquio }\end{array}$ & $\begin{array}{l}\text { Valvula venae cavae } \\
\text { inferioris }\end{array}$ & $\begin{array}{l}\text { Valve of inferior vena } \\
\text { cava }\end{array}$ & $\begin{array}{l}\text { Válvula da veia cava } \\
\text { inferior }\end{array}$ & $\begin{array}{l}\text { Válvula de la vena } \\
\text { cava inferior }\end{array}$ \\
\hline Harveys ligament & $\begin{array}{l}\text { Ligamento de } \\
\text { Harvey }\end{array}$ & $\begin{array}{l}\text { Ligamento de } \\
\text { Harvey }\end{array}$ & $\begin{array}{l}\text { Lig. arteriosum (Ductus } \\
\text { arteriosus) }\end{array}$ & $\begin{array}{l}\text { Ligamentum } \\
\text { arteriosum (Ductus } \\
\text { arteriosus) }\end{array}$ & $\begin{array}{l}\text { Lig. arterial (Ducto } \\
\text { arterial) }\end{array}$ & $\begin{array}{l}\text { Lig. arterioso } \\
\text { (Conducto arterioso) }\end{array}$ \\
\hline His, Bundle of & Feixe de His & Fascículo de His & $\begin{array}{l}\text { Fasciculus } \\
\text { atrioventricularis }\end{array}$ & $\begin{array}{l}\text { Atrioventricular } \\
\text { bundle }\end{array}$ & $\begin{array}{l}\text { Fascículo } \\
\text { atrioventricular }\end{array}$ & $\begin{array}{l}\text { Fascículo } \\
\text { atrioventricular }\end{array}$ \\
\hline Keith-Flack, Node of & Nó de Keith-Flack & $\begin{array}{l}\text { Nodo de Heith- } \\
\text { Flack }\end{array}$ & Nodus sinuatrialis & Sinuatrial node & Nó sinoatrial & Nodo sino-atrial \\
\hline Kents bundle & Feixe de Kent & Fascículo de Kent & $\begin{array}{l}\text { Fasciculus } \\
\text { atrioventricularis }\end{array}$ & $\begin{array}{l}\text { Atrioventricular } \\
\text { bundle }\end{array}$ & $\begin{array}{l}\text { Fascículo } \\
\text { atrioventricular }\end{array}$ & $\begin{array}{l}\text { Fascículo } \\
\text { atrioventricular }\end{array}$ \\
\hline Kochs node & Nó de Koch & Ganglio de Koch & Nodus sinuatrialis & Sinuatrial node & Nó sinoatrial & Nodo sino-atrial \\
\hline $\begin{array}{l}\text { Leonardo (da Vinci)s } \\
\text { cord }\end{array}$ & $\begin{array}{l}\text { Corda de Leonardo } \\
\text { (da Vinci) }\end{array}$ & $\begin{array}{l}\text { Cordón de } \\
\text { Leonardo (da Vinci) }\end{array}$ & $\begin{array}{l}\text { Trabecula } \\
\text { septomarginalis }\end{array}$ & $\begin{array}{l}\text { Septomarginal } \\
\text { trabecula; Moderator } \\
\text { band }\end{array}$ & $\begin{array}{l}\text { Trabécula } \\
\text { septomarginal }\end{array}$ & $\begin{array}{l}\text { Trabécula } \\
\text { septomarginal }\end{array}$ \\
\hline Lowers tubercle & Tubérculo de Lower & Tubérculo de Lower & $\begin{array}{l}\text { Tuberculum } \\
\text { intervenosum }\end{array}$ & Intervenous tubercle & $\begin{array}{l}\text { Tubérculo } \\
\text { intervenoso }\end{array}$ & $\begin{array}{l}\text { Tubérculo } \\
\text { intervenoso }\end{array}$ \\
\hline Marshalls vein & Veia de Marshall & Vena de Marshall & V. obliqua atrii sinistri & $\begin{array}{l}\text { Oblique vein of left } \\
\text { atrium }\end{array}$ & $\begin{array}{l}\text { V. oblíqua do átrio } \\
\text { esquerdo }\end{array}$ & $\begin{array}{l}\text { V. oblicua del atrío } \\
\text { izquierdo }\end{array}$ \\
\hline Purkinje fibres & Fibras de Purkinje & Fibras de Purkinje & Rr. Subendocardiales & $\begin{array}{l}\text { Subendocardial } \\
\text { branches }\end{array}$ & Rr. Subencodárdicos & Rr. Subendocrárdicos \\
\hline Tawara, Node of & Nó de Tawara & Nodo de Tawara & $\begin{array}{l}\text { Nodus } \\
\text { atrioventricularis }\end{array}$ & $\begin{array}{l}\text { Atrioventricular node } \\
\text { Openings of smallest }\end{array}$ & Nó atrioventricular & $\begin{array}{l}\text { Nodo } \\
\text { atrioventricular }\end{array}$ \\
\hline **Thebesian foramina & Forame de Tebésio & & $\begin{array}{l}\text { Foramina venarum } \\
\text { minimarum }\end{array}$ & cardiac veins & $\begin{array}{l}\text { Forames das veias } \\
\text { mínimas }\end{array}$ & $\begin{array}{l}\text { Orificio de las venas } \\
\text { cardíacas mínimas }\end{array}$ \\
\hline Thebesian valve & Valva de Tebésio & Válvula de Tebesio & Valvula sinus coronarii & $\begin{array}{l}\text { Valve of coronary } \\
\text { sinus }\end{array}$ & $\begin{array}{l}\text { Válvula do seio } \\
\text { coronário }\end{array}$ & $\begin{array}{l}\text { Válvula del seno } \\
\text { coronário }\end{array}$ \\
\hline Thebesian veins & Veias de Tebésio & Venas de Tebesio & $\begin{array}{l}\text { Vv. cardiacae minimae; } \\
\text { Vv. cordis minimae }\end{array}$ & Small cardiac veins & $\begin{array}{l}\text { Vv. cardíacas } \\
\text { mínimas }\end{array}$ & Vv. cardiacas mínimas \\
\hline Valsava, Nodules of & Nódulos de Valsava & Nódulos de Valsava & $\begin{array}{l}\text { Noduli valvularum } \\
\text { semilunarium }\end{array}$ & $\begin{array}{l}\text { Nodules of semilunar } \\
\text { cusps }\end{array}$ & $\begin{array}{l}\text { Nódulos das } \\
\text { válvulas seminulares }\end{array}$ & $\begin{array}{l}\text { Nódulos de las } \\
\text { valvas semilunares }\end{array}$ \\
\hline Valsava, Sinus of & Seio de Valsava & Seno de Valsava & Sinus aortae & Aortic sinus & Seio da aorta & Seno aórtico \\
\hline Wrisberg, Ganglion of & $\begin{array}{l}\text { Gânglios de } \\
\text { Wrisberg }\end{array}$ & $\begin{array}{l}\text { Ganglio de } \\
\text { Wrisberg }\end{array}$ & Ganglia cardiaca & Cardiac ganglia & $\begin{array}{l}\text { Gânglios cardíacos } \\
\text { (parte torácica) }\end{array}$ & Ganglios cardíacos \\
\hline Zuckerkandl, Bodies of & $\begin{array}{l}\text { Corpos de } \\
\text { Zuckerkandl }\end{array}$ & $\begin{array}{l}\text { Cuerpos de } \\
\text { Zuckerkandl }\end{array}$ & $\begin{array}{l}\text { Corpora paraaortica; } \\
\text { Glomera aortica }\end{array}$ & $\begin{array}{l}\text { Para-aortic bodies; } \\
\text { Aortic glomera }\end{array}$ & $\begin{array}{l}\text { Glomos para- } \\
\text { aórticos }\end{array}$ & $\begin{array}{l}\text { Cuerpos } \\
\text { paraaórticos; } \\
\text { Cuerpos aórticos }\end{array}$ \\
\hline
\end{tabular}

* The fold of the left vena cava is a small fold of serous pericardium, in the embryo, between the left pulmonary artery and upper left pulmonary vein, behind the left end of the transverse sinus. It encloses the ligament of the left vena cava, which is a remnant of the anterior cardinal vein (1; pp 393-4).

**A number of small openings are scattered in the walls of the atrium. These openings, which are termed foramina venarum minimarum, are the terminations of small venous channels, the venae cordis minimae. These openings occur in all chambers of the heart and several types have been described (R.T. Grant and L.E. Viko, Heart, 15:103, 1929), according to (1) 
Morgagni disease, Stokes-Adams disease, MorgagniAdams-Stokes syndrome, Spens syndrome, Stokes-Adams syndrome, a syndrome characterized by slow or absent pulse, vertigo, syncope, convulsions, and sometimes Cheyne-Stokes respiration; usually as a result of advanced AV block or sick sinus syndrome, which are synonumous [20]. According Waseem et al. [15], the value of eponymous is their correct understanding of the meaning, without which their use can be confusing and even dangerous. They reported that over the last three decades an error in performing Finkelstein's test has crept into the English literature, in both textbooks and journals. Its incorrect description persisted in literature for 50 years, before it was pointed out by Elliot BG, in 1927. This error can produce a false-positive, and if relied upon, a wrong diagnosis can be reached. Eponyms are not only hard to learn, inaccurate, redundant and ethnocentric. They are clearly old fashioned. They are a bit like using ounces and inches in a modern research lab: they get the job done, but they are cumbersome and not recognized by the international community [1].

Use of eponyms without reflection or even knowledge of the person concerned causes other problems. A common flaw is that eponyms usually refer to one person whereas scientific discoveries often reflect a group effort over time. Eponyms lack accuracy, lead to confusion and hamper scientific discussion in a globalized world. Instead of using eponyms, we should use our interest in medical history to provide fair and truthful accounts of scientific discoveries and to dissect individual contributions [21]. The bottom line is that all this randomness, inconsistency, idiosyncrasy, and confusedness are heavily influenced by local geography and culture, which is part of their beauty [17].

On one hand, eponyms are everywhere and widely used - 8531 eponyms described in 4292 main entries. These eponyms are linked to 3409 persons: 130 female and 3279 male according to the website Whonamedit.com (http:// www.whonamedit.com/). Every day we have the opportunity to hear eponyms either on the street or in the ward. They are present in the textbooks, in the mass media, on the web, and as incredible it may seem, in the latest reviews of the international classification of diseases made by the World Health Organization (WHO). It can be surmised that they are widely recognized, their eradication, even if it is desirable, would demand an effort of overwhelming proportion [17]. Efforts should be driven to avoid trivial nomenclature in the modern era of Evidence Based Medicine and a proper descriptive nomenclature introduced, thus creating systems which would be easy to use and not fictitious [15]. There is no shortage of people who will be happy to argue eponyms should be abolished, but the propositions behind many of these lines of reasoning, however, are not always convincing, to some public health scientists. On the other hand few people are prepared to deal with the contrary view. Withworth [17] is not the only who feels this way, and in her professional opinion this can only be ascribed to the widely known human propensity to enjoy tilting at windmills. "Eponyms are here to stay", she says. This is the same opinion of Swee [8] who says "despite all the inconveniences, medical eponyms will continue to be used because there is a sense of history to their use".

The Medicine is more colorful due to the eponyms, once they provide a convenient short hand for the profession and the community alike, and most importantly, they are embedded in medical traditions and culture in our history $[16,17]$. The eponyms have long been part of the tradition of Medicine, connecting us with the eminent minds of the past, those who astute observations have added to the rich culture of Medicine. You have probably noticed that in our clinical years we have been drowning in a sea of eponyms [22], such as those bearing the names of three of the giants of Guy's Hospital, Addison, Bright and Hodgkin $[17,21,22]$. Why to legislate against eponyms, if as we come to understand more of the basis of diseases, the trend of current usage will tend to change? If we abolish the eponyms in Medicine, should we abolish the eponyms that enable Medicine, such as Boyle's law, the Joule, the Kelvin, the Hertz? [17].

According to Scully and Baum [18], Eugene (1983) in a lengthy essay on eponyms, summarizes as follows:

"Whatever such disadvantages eponyms may have, I believe they are outweighed by their benefits. Eponyms remind us that science and scholarship are the work of dedicated people. They allow us to immortalize sometimes obscure but deserving persons. It is clear that they represent a natural language way of expressing complex ideas and it is for this reason that they have often been cited as a useful first approach to searching with titleword and citation indexes, as well as with controlled vocabularies".

Based on what we have discussed above, we really would like to take this discussion further, but other than that, we also have to start talking about the subject of this paper: Anatomical Eponyms currently used in Cardiology. Regarding the eponyms used in Cardiology, they are a form of medical shorthand [16,17]. Should we really speak of congenital cyanotic heart disease due to ventricular septal defect, pulmonary stenosis, right ventricular hypertrophy, and aortic dextroposition rather than Fallot's tetralogy? [17], or maybe we could speak about an electrocardiographic pattern sometimes associated with paroxysmal tachycardia which consists of short PR interval (usually 0.1 second or less; occasionally normal) together with a prolonged QRS complex with a slurred initial component (delta wave) instead of speaking of Wolff-Parkinson-White syndrome, or we 
might want to say: any forced expiratory effort ("strain") against a closed airway, whether at the nose and mouth or at the glottis, the reverse of Müller maneuver; because high intrathoracic pressure impedes venous return to the right atrium, this maneuver is used to study cardiovascular effects of raised peripheral venous pressure and decreased cardiac filling and cardiac output, as well as post-strain responses [20]. A greater preload stretch) on cardiac muscle fibers prior to contraction increases their force of contraction. Within limits, the more the heart is filled during diastole, the greater the force of contraction during systole - a relationship known as the Frank-Starling law of the heart [11].

In our study we do not want to discuss this kind of eponym, but the anatomical eponym that is used at the expense of an anatomical structure. That is our main concern in this study. Anatomy has an international vocabulary that is the foundation of medical terminology, which enables precise communication among health professionals worldwide, as well as among scholars in basic applied health sciences. The eponyms listed in Table 1 are those commonly used by cardiologists. This study aims at to reduce the ambiguity and misunderstanding of these terms. Eponyms and terms that are not used in the International Anatomical terminology must appear in parenthesis. For example: a very common term still used nowadays is "internal mammary artery" instead of the correct anatomical term "internal thoracic artery". Thus it must be written as follows: internal thoracic artery (internal mammary artery). This is another alternative we can present to the Health and Applied Health Sciences Professional the new International terminology.

In the present study we made an extensively research throughout the best well-known Atlas and Textbooks in Human anatomy and we were able to compare the research with the results listed in Table 1. According to our results, you have probably noticed that what was discussed above is precisely what occurs in Table 1.

For example: Nodules of semilunar cuspis are named after Arantius and Valsalva; Atrioventricular node after Aschoff-Tawara and Tawara; Ligamentum arteriosum (Ductus arteriosus) after Botallo and Harvey; Atrioventricular bundle after $\mathrm{His}$ and Kent; and Sinuatrial node after Keith-Flack and Kochs. At this point I would like to propose, in order to further elaborate on this matter, to go really very deep into this subject, to invite you all to a journey to the past. I invite you go back to the 60 s.

We are going to review Gardner et al. [1], Chapter 34, pp 392-417. They used the following: "The conducting system of the adult heart comprises the sinu-atrial node, the atrioventricular node, and the atrioventricular bundle with its two limbs and the subendocardial plexus of Purkinje fibers. [...] The atrioventricular bundle, its two limbs, and the Purkinje fibers conduct the impulse from [...]". All other anatomical terms are according to the new International Anatomical Terminology. At the end of the book they included a Glossary of Eponymous Terms with the following warning: "Although eponyms should be avoided (see footnote 5, p.5), they are in common use and a student frequently has occasion to seek the meaning of such terms. This glossary provides a list of anatomical eponyms, many of which are in common usage. [...] Separate entries are used here to distinguish two or more workers who have the same surname (e.g., Meckel, Müller,and Petit).

Moving forward in time let's look at O'Rahilly \& Müller [2], twenty-three years ahead. Chapter 23, pp 202-215. "The conducting system comprises the sinu-atrial (SA) node, the atrioventricular (AV) node, and the AV bundle, with its two limbs and the subendocardial plexus of Purkinje fibers. At the end of the book, he presents the same Glossary of Eponymous Terms as that of Gardner et al. [1].

Keeping on our journey to the past, we are going now to revisit one of the bestsellers in Human Anatomy: Gray's Anatomy [23]. On page 705, Figure 6.34, the following eponyms "tendon of Todaro", an inconstant tendinous structure that extends from the right fibrous trigone of the heart toward the valve of the inferior vena cava; "Triangle of Koch", [TA], *a triangular area on the lateral surface of the caudal half of the mesencephalon, bordered caudally by the slight prominence of the lateral lemniscus, dorsally by the base of the inferior colliculus and the brachium of the superior colliculus, and ventrally by the crus cerebri. Syn: triangle of fillet, Reil triangle, trigone of fillet, lemniscal trigone, which corresponds to the anatomical term Triangle of sinu-atrial node [20]. On page 721, Figures 6.54-6.55, the eponym "Bachman's bundle", [*] division of the theoretical anterior internodal tract that continues into the left atrium providing a specialized path for interatrial conduction. The anatomic reality of this structure has been disputed [20]. On page 722 , the correct way of expressing an eponym is used: The atrioventricular bundle (His 1893). On the same page, three eponyms are cited with the following explanation: "The Interatrial and intermodal conduction paths some current text dismiss any specialized interatrial and intermodal conduction pathways (Anderson et 1974, 1975, Anderson, 1975; Rushmer 1976) or consider that such could have no demonstrable physiological role (Marriot \& Myerberg, 1978). However, others have postulated such specialized routes Wenckeback 1908, Thorel 1909, 1910, and Bachmman 1916. The anterior internodal tract (Bachamman's bundle); the middle internodal tract (of Wenckbach), and the posterior internodal tract (of Thorel). On page 731, the following eponym is used "Kugel's anastomotic artery", 'arteria anastomotica auricularis magna' (Syn: **atrial anastomotic branch of circumflex branch of left coronary artery [20]) was describerd by Kugel in 1927, as a constant circumflex branch. This anastomosis is controversial, 
apparently accepted by James (1974) but denied by Baroldi \& Scomazzoni (1967). James considered it an auxiliary supply to the atrioventricular node.

Keeping on our journey throughout the time-line, we go to Snell [24]. On page 97, he refers to the subendocardial plexus of Purkinje fibers* (foot note: The specialized cardiac muscle fibers that form the conducting system of the heart are known as Purkinje fibers). On the same page, Snell uses the following terms but no eponyms referring to them: anterior, middle, and poster internodal pathways, as occurs in [23]. The Anatomical Chart Company [25], on plate 54, refers to no eponyms at all. Harold Ellis [26]. On page 35, the right form to express an eponym is used, i.e. the anatomical structure followed by the associated eponym in parentheses: "atrioventricular bundle" (of His).

Moore \& Dalley [3] is another important textbook, already in its 6th edition, 2009. On page 138, the only reference to an eponym is made: subendocardial branches (Purkinje fibers). From 1999, we go to 2000, to visit one of the most famous and well-known Atlas of Human Anatomy: Sobotta [27]. On page 84, Figure 853, in spite of the Anatomical Terminology has been written in Latin, the following eponyms are used: Nodulus sinuatrialis (Node of Keith-Flack), Nodus atrioventricularis (Aschoff-Tawara node), and Fasciculus atrioventricularis (Bundle of His); on page 90, Figure 868, Lig. Arteriosum (ductus arteriosus) (Boatallo).

Finally, we have changed the century and the first textbook we peered is Tortora Grabowski [28]. On Chapter 20, page 636, The Cardiovascular system: The Heart, on page 650, Figure 20.10, Atrioventricular (AV) bundle (Bundle of His); Conduction myofibers (Purkinje fibers) are used as well as in the text below the figure. Now, a book for the Allied Health Sciences Students envisioned by Dr. Ruth L. Memmler and published by Cohen and Wood [29]. On page 253, Figure 14.6, Atrioventricular bundle (bundle of His) and Purkinje fibers and page 254, the atrioventricular bundle, also known as the bundle of His.

In 2002, Moore \& Agur [30] used no eponyms. In 2003, Van De Graaf [31] was translated to Portuguese by Dr. Nader Wafae. On page 552, the atrioventricular bundle is ascribed to Bundle of His, as well as the subendocardial branches are inferred to (Purkinje fibers).

In 2005, Agur and Dalley [32], on page 62, Figure 1.56 and text, the anatomical term Subendocardial branches is followed by his eponym in parentheses (Purkinje fibers). Now, moving on to Drake, Vogl, and Mitchell [33], on page 177, the subendocardial plexus of conduction cells (Purkinje fibers) is the only eponym used throughout the book. Also, in 2005, Gerard J. Tortora [34] on page 438 as well as in Figure 14.9 used the following eponyms: the atrioventricular (AV) bundle (also known as the bundle of His; and the large-diameter of Purkinje fibers. Petra Köpf-Maier [35], translated by Prof. Dr. Werneck in 2006 from the original
Wolf-Heidegger's atlas of human anatomy, 6th edition, on page 138, Figure 138; page 139, Figure 139; page 140, Figure 140 refers to Lig. arteriosum (Ductus arteriosus) as (BOTALLO); on page 148, Figure 148 a, refers to Nodules of semilunar cuspis as (ARANTIUS); page 148, Figure b, Valve of inferior vena cava as (EUSTACHI), and Valve of coronary sinus as (THEBESIUS); on page 149, Figure 149, the Aortic sinus is referred as (VALSALVA), Nodules of semilunar cuspis as (ARANTIUS); page 151, Figure 151 a, Nodules of semilunar cuspis as (ARANTIUS), Atrioventricular bundle as $(H I S)$; page 156 , Figure 156, Sinuatrial node (KEITHFLACK); Valve of coronary sinus as (THEBESIUS), Atrioventricular node (ASCHOFF-TAWARA), Atrioventricular bundle as (HIS), Subendocardial branches (PURKINJE), Atrioventricular bundle as (HIS); Figure b, Valve of coronary sinus as (THEBESIUS), Atrioventricular node (ASCHOFF-TAWARA), Atrioventricular bundle as (HIS), and Valve of inferior vena cava as (EUSTACHI); pages and figures 160-161 Lig. arteriosum (Ductus arteriosus) as (BOTALLO); page 161, Figure 161, Oblique vein of left atrium (MARSHALL). A list of current eponyms used is found at the end of the book.

In 2009, Frederic Martini; Michael Timmons; Robert Tallitsch [36] was translated to Portuguese by Daniella Franco Cursio, ArtMed, 2009. On page 563, subendocardial branches are referred as (Purkinje cell or fibers), in Figure 21.11, page 563, AV bundle as (Bundle of His). Also in 2009, Gerard J. Torotora and Bryan Derrickson [37] on page 732 used atrioventricular (AV) bundle (also known as bundle of His); the large-diameter Purkinje fibers, but no reference to subendocardial branches; on page 733, Figure 20.10, Atrioventricular (AV) bundle refers to (bundle of His), but again Purkinje fibers have no reference to subendocardial branches. Patrick W. Tank and Thomas R. Gest [38], with collaboration of William Burkel, on plates ranging from 421 to 4-28 (pp. 180-9) refers to no eponyms at all.

At the end our journey, we meet Moore, Agur, and Dalley [39], published by Lippincott Williams \& Wilkins, 2011. Only on page 97 subendocardial branches are referred to (Purkinje fibers), as well as in Figure 1.39 on the same page. It is worth mentioning that all the textbooks cited here are fully of Anatomical variations, trauma, diagnostic procedures, surgical procedures and pathologies regarding the heart, such as cardiac tamponade, percussion of the heart, atrial and ventricular septal defects, thrombi, valvular heart disease, coronary artery disease or coronary heart disease, myocardial infarction, coronary atherosclerosis, coronary bypass graft, coronary angioplasty, variations of coronary arteries, echocardiography, cardiac referred pain, injury to conducting system of heart, and so many other well-known conditions.

At the risk of sounding obvious, it seems rather unnecessary to say that based on our results, the current 
anatomical eponyms used in Cardiology are fewer and not as frequently used as the non-anatomical cardiological eponyms. Anybody interested in fuller etymological details should consult one of books mention in the references.

\section{CONCLUSIONS}

Eponyms are widely used in contemporary life. Eponyms lack accuracy, lead to confusion and hamper scientific discussion. In reality, eponyms are still widely used in clinical setting and you will have to learn eponyms in order to understand clinicians who cling to archaic terms in coming years. Eponyms are not only hard to learn, inaccurate, redundant and ethnocentric, they are only old fashioned. Many authors have drawn attention to the confusion created by the use of many eponyms with identical names or the redundancy of multiple eponyms describing the same condition. As we could see in the discussion abovementioned, eponyms bring color to Medicine, and they are embed medical traditions and culture in our history, which is part of their beauty.

In the words of an American philosopher, Ralph Waldo Emerson, "There is properly no history, only biography". Howard Burchel, a former cardiologist at the Mayo Clinic offered the same advice: "if an eponym is obfuscatory, it should be culled; if it enhances clarity and communication, it is richly deserved". To prevent the chances of mistakes in clinical practice and errors in scientific writings, we proposed that structured definitions which should be universally accepted ad friendly used, and the credit when and where due. We only must abolish the eponyms when they are used at the expense of an anatomical structure. Otherwise, as suggested by the Hippocratic oath: "I shall not be the cavalier accoucheur of an eponym or the uncritical promoter of a new one".

* The explanation is provided by the STEDMAN'S ELECTRONIC MEDICALDICTIONARY, 2004 [20]

**The explanation is provided by the STEDMAN'S ELECTRONICMEDICALDICTIONARY, 2004 [20]

\section{REFERENCES}

1. Gardner E, Gray DJ, O'Rahilly R. Anatomy: a regional study of human structure. Philadelphia: W. B. Saunders Company; 1960.

2. O'Rahilly R, Müller F. O'Rahilly basic human anatomy: a regional study of structure. Philadelphia: W.B. Saunders Company; 1983.
3. Moore KL, Dalley II AF, Donohoe LS, Moore ME. Clinically oriented anatomy. 4th ed. Philadelphia: Lippincott Williams \& Wilkins; 1999.

4. Galvão R. Vocabulário etymológico, orthográphico e prosódico das palavras portuguezas derivadas da lingua grega. Rio de Janeiro: Livraria Francisco Alves; 1900.

5. Woerdeman M. Nomina anatomica parisiensia (1955) et BNA (1895). Utretch: A. Oosthoek Publ.; 1957.

6. Beau A. Nomina anatomica. Revisés par le Comité International de la Nomenclature Anatomique designé lors du Cinquième Congrés International d'Anatomie réuni à Oxford em 1950. London: Spottiswoode; Coclchester: Ballantyne et Cie.; 1955.

7. Field EJ, Harrison RJ. Anatomical terms: their origin ad derivation. Cambridge: W. Heffer \& Sons; 1957.

8. Swee CTE. Eponyms in Medicine. SMA News 2007;39(8):204.

9. Gilliland KO, Montgomery RL. Anatomists and eponyms: an illustrated history of Anattomy. England: Notthingham University Press; 2010.

10. Cole FJ. A history of comparative anatomy from Aristoteles to the eighteenth century. London: McMillan; 1944.

11. Grinberg M. Epônimos em Cardiologia: homenagem e exemplo. São Paulo: Roca; 1999.

12. Federative Committee on Anatomical Terminology (FCAT), Federative Committee on Terminologicalo Terminology. Terminologia anatomica. International anatomical terminology. New York: Thieme Stuttgart; 1998.

13. Sociedade Brasileira de Anatomia (CFTA), Comissão Federativa da Terminologia Anatômica. Terminologia anatômica. Terminologia anatômica internacional. São Paulo: Manole; 2001.

14. Sociedad Anatómica Española (SAE), Comité Federal sobre la Termiología Anatómica. Terminología anatómica. Terminología anatómica internacional. Madrid: Médica Panamericana; 2001.

15. Waseem M, Khan M, Hussain N, Giannoudis PV, Fischer J, Smith RM. Eponyms: errors in clinical practice and scientific writing. Acta Orthop Belg. 2005;71(1):1-8.

16. Nordqvist C. Head-to-head: should eponyms be? BMJ 2007;355:424-5. [cited 2010 Oct. 22]. Available from: URL: http://www.medicalnewstoday.com

17. Withworth JA. Should eponyms be abandoned? No. BMJ. 2007;335(7617):425.

18. Scully C, Baum B. Marathon of eponyms. Danvers: John Willey \& Sons; 2009. [cited 2010 Oct. 22]. Available from: URL: http://www.blackwellmunksgaard.com 
19. Dirckx JH. The synthetic genitive in medical eponyms: is it doomed to extinction? Panace@ 2001;2(5):15-24.

20. Stedman's electronic medical dictionary: version 6.0, 2004. [CD-ROM]

21. Woywodt A, Matteson E. Should eponyms be abandoned? Yes. BMJ. 2007;335(7617):424.

22. Weyden MBVD. Expunging eponyms. MJA 2007;187(6):321.

23. Williams PL, Warwick R, Dyson M, Bannister LH. Gray's anatomy. 37th ed. London: Churchill Livingstone; 1989.

24. Snell RS. Clinical anatomy for medical students. 5th ed. Boston: Little, Brown and Company; 1995.

25. Oliver MV, Burkel WE. Rapid review anatomy reference guide. Skokie: Anatomical Chart Company; 1996.

26. Ellis H. Clinical anatomy: a revision and applied anatomy for clinical students. 9th ed. United Kingdom: Blackwell Science; 1997.

27. Putz R, Pabst R. Sobottta atlas der anatomie des menschen. München: Urban \& Fischer; 2000. Band 2: Rumpf, eingeweide, untere extremität.

28. Tortora GJ, Grabowski SR. Principles of anatomy and physiology. 9th ed. New York: John Wiley \& Sons; 2000.

29. Cohen BJ, Wood Dl. Memmler's the human body in health and disease. 9th ed. Philadelphia: Lippincott Williams \& Wilkins; 2000.
30. Moore KL, Agur AMR. Essential clinical anatomy. 2nd ed. Philadelphia: Lippincott Williams \& Wilkins; 2002.

31. Van De Graaff KM. Anatomia humana. $6^{\text {a }}$ ed. Trad. Rev. Nader Wafae. São Paulo: Manole; 2003.

32. Agur AMR, Dalley AF. Grant's atlas of anatomy. 11th ed. Philadelphia: Lippincott Williams \& Wilkins; 2005.

33. Drake RL, Vogl W, Mitchell AWM. Gray's anatomy for students. Philadelphia: Elsevier Churchill Livingstone; 2005.

34. Tortora GJ. Principles of human anatomy. 10th ed. Danvers: John Wiley \& Sons; 2005.

35. Wolf-Heidegger Atlas de anatomia humana. Trad. Hélcio Werneck. $6^{\text {a }}$ ed. Berlin: Petra Köpf-Maier/Rio de Janeiro: Guanabara Koogan; 2006.

36. Martini FH, Timmons MJ, Tallitsch RB. Anatomia humana. Trad. Daniela Franco Curcio. $6^{\mathrm{a}}$ ed. Porto Alegre: Artmed; 2009.

37. Tortora GJ, Derrickson B. Principles of anatomy and physiology. 12th ed. Danvers: John Wiley \& Sons; 2009.

38. Tank PW, Geest TR, Burkel W. Lippincott Williams \& Wilkins atlas of anatomy. Philadelphia: Lippincott Williams \& Wilkins; 2009.

39. Moore KL, Agur AMR, Dalley AF. Essential clinical anatomy. 4th ed. Philadelphia: Lippincott Williams \& Wilkins; 2011. 